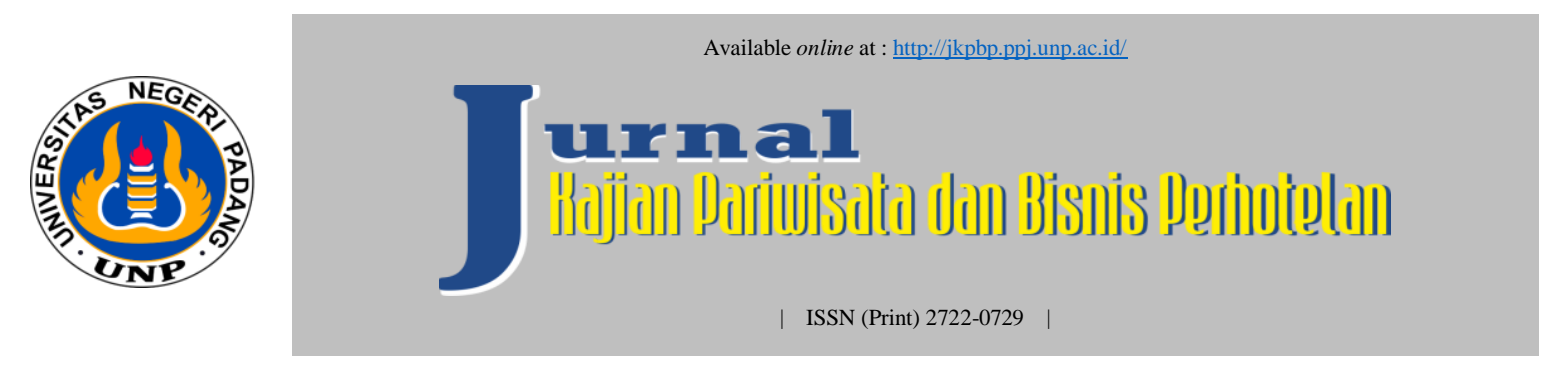

\title{
Strategi Pengembangan Aktivitas Wisata Di Objek Wisata Pantai Padang
}

\author{
Nurmailis $^{1}$, Hijriyantomi Suyuthie ${ }^{2}$ \\ ${ }^{1}$ Universitas Negeri Padang \\ ${ }^{2}$ Universitas Negeri Padang \\ Email: mailisnur5@gmail.com,hsuyuthie@fpp.unp.ac.id
}

\begin{abstract}
ABSTRAK
Judul penelitian ini adalah strategi pengembangan aktivitas wisata di objek wisata pantai Padang. Penelitan merupakan penelitian deskriptif kualitatif dengan metode survey. Teknik pengumpulan datanya menggunakan observasi, wawancara, dokumentasi. Teknik pengambilan sampel menggunakan purposive sampling dan snowball sampling. Penelitian ini melibatkan beberapa informan diantaranya: 1 orang pegawai Dinas Pariwisata dan Kebudayaan Kota Padang, 2 orang masyarakat sekitar, dan 3 orang pengunjung.

Hasil penelitian menunjukkan bahwa: 1) Kekuatan pengembangan aktvitas wisata di objek wisata Pantai Padang adalah lokasi ditengah kota dan mudah dijangkau, pemandangan alam yang indah, pasir landai cocok untuk bermain voli, disediakan arena skateboarding, tersedia panggung untuk festival budaya dan berkemah, jalan mulus dan lurus untuk bersepeda. 2) Kelemahan pengembangan aktivitas wisata di objek wisata Pantai Padang adalah kurangnya spot berfoto, toilet sedikit dan kotor, tidak ada jalur khusus bersepeda, arena skateboaring yang belum terlalu mulus, masih banyaknya sampah berserakan, tidak ada pagar pengaman untuk bermain skateboarding, tidak adanya pembatas untuk aktivitas banana boat. 3) Peluang dari pengembangan aktivitas wisata di Pantai Padang adalah bisa menjadi peluang bisnis untuk masyarakat sekitar dalam penyewaan sepeda, alat kemah, memperkenalkan budaya Sumbar ke pengunjung lokal/mancanegara. 4) Ancaman pengembangan aktivitas wisata di objek wisata Pantai Padang adalah keadaan alam seperti hujan, badai, ombak besar dan tsunami, bisa menjadi aktivitas negatif, abrasi pantai, terjadi kecelakaan.

Strategi pengembangan aktivitas wisata di objek wisata Pantai Padang adalah a) menambah area berfoto, b) menambah fasilitas toilet, c) membuat jalur khusus bersepeda, membuat pembatas aktivitas banana boat, memuat pagar arena skateboarding.
\end{abstract}

Kata Kunci: Strategi, Pengembangan, Aktivitas Wisata 


\section{PENDAHULUAN}

Indonesia mempunyai banyak keberagaman, mulai dari adat, suku, sumber daya alam yang kaya, bahasa, agama,dan budaya. Sumber daya alam Indonesia jika di kelola baik dapat memberi pendapatan besar dan dapat memajukan Indonesia. Salah satunya yaitu bidang pariwisata. Menurut [1] pariwisata adalah perjalanan terencana dilakukan kelompok ataupun indvidu untuk mendapat kesenangan. Sedangkan menurut [2] pariwisata yaitu bermacam kegiatan wisata dengan banyaknya layanan dan fasilitas oleh pengusaha, masyarakat, pemerintah. Sedangkan menurut [3] pariwisata yaitu hal yang berkaitan dengan perjalanan sementara bertujuan menikmati daya tarik serta objek wisata secara sukarela. Sedangkan menurut [4] industri bergaya baru dapat meningkatkan ekonomi dalam hal pemasukan, lowongan pekerjaan , tarif kehidupan, dan sektor produksi lainnya.

Salah satu sektor pariwisata cukup berkembang pesat ialah Sumatera Barat. Padang adalah ibu kota Sumatera Barat mempunyai objek wisata pantai, salah satunya ialah Pantai Padang. Pantai Padang berada ditengah kota di Kecamatan Padang Barat, dengan jarak dari Purus sampai muara Batang Arau.

Objek wisata wajib mempunyai aktivitas wisata yang bisa dilakukan oleh pengunjung yang berkunjung. Menurut [5] Objek wisata yaitu hal yang berkaitan dengan objek yang dapat menarik wisatawan berkunjung antara lain bangunan sejarah, keadaan alam, kebudayaan, serta rekreasi modern. Pengertian aktivitas Menurut [6] kegiatan yang dilakukan secara fisik ataupun non fisik. Lain halnya menurut [7] aktivitas wisata ialah aktivitas wisatawan ataupun motivasi untuk berkunjung ke destinasi dalam waktu setengah hari bahkan berminggu - minggu. Beberapa aktivitas wisata yng dilakukan wistawan ialah, hiking, bersampan/berakit, melihat pemandangan alam, berlayar, camping, bersepeda, panjat tebing, berlayar, photography, melihat seni dan budaya lokal, belanja souvenir. Indikator aktivitas wisata menurut [8] adalah aktivitas budaya, aktivitas khusus, aktivita alam.

Aktivitas-aktivitas pada objek wisata akan menentukan tingkat kepuasan pengunjung terhadap objek wisata tersebut. Sebagaimana dikatakan [9] bahwa apabila sarana dan aktivitas wisata dapat berfungsi dengan baik, maka akan menimbulkan kepuasan bagi pengunjung. Kepuasan pengunjung ini nanti akan berdampak kepada image (citra) objek wisata. Pengunjung yang puas akan bercerita tentang objek wisata tersebut kepada kenalan-kenalannya sehingga akan menjadi promosi bagi objek wisata tersebut.

Berdasarkan pra penelitian selama ini, objek wisata Pantai Padang tidak memiliki banyak aktivitas wisata yang dilakukan pengunjung. Aktivitas wisata yang dilakukan di Pantai Padang diantaranya, aktivitas berfoto, wisata kuliner di tepi pantai maupun cafe-cafe yang tersedia di pinggir jalan. Satu lagi permasalahan yang peneliti temui adalah hilangnya penyewaan sepeda untuk orang dewasa. Tidak banyak aktivitas khusus yang dapat di lakukan untuk anak kecil maupun orang dewasa.

Hasil wawancara pra penelitian dengan 10 orang pengunjung, seluruh pengunjung mengatakan bahwa masih kurangnya aktivitas yang dapat dilakukan di pantai Padang. Dibandingkan pantai lainnya, pantai Padang masih minim aktivitas sehingga membuat pengunjung tidak dapat melakukan banyak hal dan merasakan kurang puas dengan aktivitas yang ada. 
Tabel 1. Data Jumlah Pengunjung Pantai Padang

\begin{tabular}{|c|c|c|}
\hline No & Tahun & Jumlah Pengunjung \\
\hline 1 & 2017 & 3,1 juta \\
\hline 2 & 2018 & 3,2 juta \\
\hline 3 & 2019 & 3,6 juta \\
\hline
\end{tabular}

Sumber: Dinas Pariwisata dan Kebudayaan Kota Padang

Daerah Pantai Padang memiliki potensi yang besar untuk meningkatkan jumlah pengunjung untuk berkunjung tiap tahunnya. Meningkatkan jumlah pengunjung dibutuhkan strategi pengembangan yang tepat.

\section{METODOLOGI PENELITIAN}

Penelitian deskriptif kualitatif menggunakan metode survey. Menurut [10] penelitian deskriptif dilakukan untuk mengetahui keberadaan variabel mandiri, baik satu variabel atau lebih tanpa membuat perbandingan atau menghubungkan dengan variabel lain. Teknik mengumpulkan data meggunakan metode observasi, wawancara, dan dokumentsi. Wawancara menurut [11] pengumpulan data serta bertanya secara langsung ke responden guna mendapatkan data mengenai hal-hal berkaitan dengan masalah. Penelitian menggunakan Purposive Sampling. Adapun teknik Purposive Sampling melibatkan beberapa informan, yaitu: satu pegawai Dinas Pariwisata dan Kebudayaan Kota Padang, dua orang masyarakat sekitar, dan tiga orang pengunjung objek wisata Pantai Padang. Data dalam penelitian ini dianalisis secara reduksi data, penyajian serta pengambilan kesimpulan.

\section{HASIL DAN PEMBAHASAN}

\section{Hasil}

Tabel 2. Matriks SWOT

\begin{tabular}{|c|c|c|}
\hline & $\begin{array}{l}\text { Kekuatan/Strenght } \text { (S) } \\
\text { 1. Lokasi ditengah kota dan } \\
\text { akses yang mudah } \\
\text { dijangkau } \\
\text { 2. Memiliki pemandangan } \\
\text { alam yang indah } \\
\text { 3. Latar belakang sunset } \\
\text { untuk berfoto menambah } \\
\text { keindahan tersendiri } \\
\text { 4. Pasir pantai yang putih } \\
\text { dan landai cocok untuk } \\
\text { bermain voli pantai } \\
\text { 5. Telah disediakan arena } \\
\text { untuk skateboarding } \\
\text { 6. Tersedianya panggung } \\
\text { yang bisa digunakan untuk } \\
\text { kegiatan festival budaya } \\
\text { 7. Jalan yang mulus dan } \\
\text { lurus untuk bersepeda }\end{array}$ & $\begin{array}{l}\text { Kelemahan/Weaknesses }(\mathbf{W}) \\
\text { 1. Kurangnya spot untuk } \\
\text { berfoto } \\
\text { 2. Toilet yang sedikit dan } \\
\text { kotor } \\
\text { 3. Tidak ada jalur khusus } \\
\text { untuk bersepeda } \\
\text { 4. Arena skateboarding yang } \\
\text { belum terlalu mulus } \\
\text { 5. Tidak adanya pagar } \\
\text { pengaman untuk bermain } \\
\text { skateboarding } \\
\text { 6. Masih banyaknya sampah } \\
\text { berserakan }\end{array}$ \\
\hline
\end{tabular}




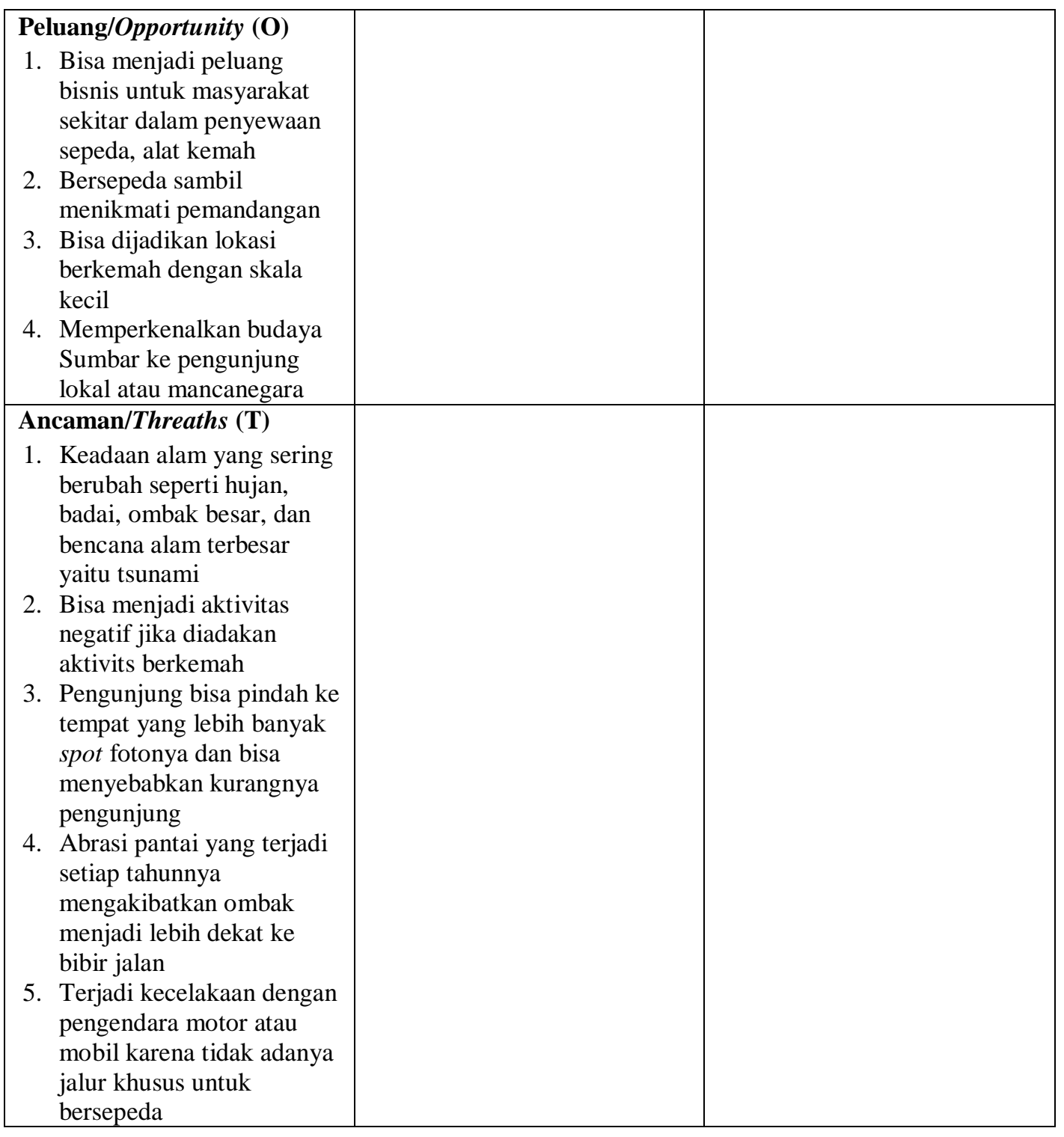

\section{Pembahasan}

Berdasarkan hasil penelitian lapangan dengan metode observasi, wawancara dan dokumentsi, maka dapat dirumuskan analisis dan strategi SWOT dalam Pengembangan Aktivitas Wisata di Objek Wisata Pantai Padang adalah berupa:

a. Analisis Aktivitas Wisata Di Objek Wisata Pantai Padang

1) Kekuatan Aktivitas Wisata

a) Lokasi ditengah kota dan akses yang mudah dijangkau

b) Memiliki pemandangan alam yang indah

c) Latar belakang sunset untuk berfoto menambah keindahan tersendiri

d) Pasir pantai yang putih dan landai cocok untuk bermain voli pantai

e) Telah disediakan arena untuk skateboarding

f) Tersedianya panggung yang bisa digunakan untuk kegiatan fesival budaya dan berkemah

g) Jalan yang mulus dan lurus untuk bersepeda 
2) Kelemahan Aktivitas Wisata
a) Kurangnya spot untuk berfoto
b) Toilet yang sedikit dan kotor
c) Tidak ada jalur khusus untuk bersepeda
d) Arena skateboarding yang belum terlalu mulus
e) Tidak adanya pagar pengaman untuk bermain skateboarding
f) Masih banyaknya sampah berserakan
g) Tidak adanya pembatas untuk aktivitas banana boat

3) Peluang Aktivitas Wisata
a) Bisa menjadi peluang bisnis untuk masyarakat sekitar dalam penyewaan sepeda, alat kemah
b) Bersepeda sambil menikmati pemandangan
c) Bisa dijadikan lokasi berkemah dengan skala kecil
d) Memperkenalkan budaya Sumbar ke pengunjung lokal atau mancanegara

4) Ancaman Aktivitas Wisata

a) Keadaan alam yang sering berubah seperti, hujan badai, ombak besar, dan bencana alam terbesar yaitu tsunami

b) Bisa menjadi aktivitas negatif jika diadakan aktivitas berkemah

c) Pengunjung bisa pindah ke tempat yang lebih banyak spot fotonya dan bisa menyebabkan kurangnya pengunjung

d) Abrasi pantai yang terjadi setiap tahunnya mengakibatkan ombak menjadi lebih dekat ke bibir jalan

e) Terjadi kecelakaan dengan pengendara motor atau mobil karena tidak adanya jalur khusus untuk bersepeda

b. Strategi SWOT

Menurut [12] strategi disusun menggunakan hasil atau analisis SWOT dengan menggabungkan indikator dalam kekuatan, kelemahan, peluang dan ancaman.

1) Strategi $\mathrm{SO}$

Strategi yang dibuat berdasarkan jalan pikiran perusahaan, yang memanfaatkan kekuatan untuk merebut peluang sebesar-besarnya.

a) Membuat jalur khusus sepeda

b) Mendorong masyarakat sekitar untuk membka penyewaan sepeda dan alat kemah

c) Memanfaatkan panggung yang sudah tersedia untuk membuat festival budaya guna mengenalkan budaya Sumatera Barat ke pengunjung lokal maupun mancanegara

2) Strategi WO

Strategi berdasarkan peluang yang ada dengan cara meminimalkan kelemahan yang ada

a) Membuat jalur khusus sepeda

b) Memperhalus arena skateboarding

c) Menambah spot untuk berfoto atau atribut berfoto

d) Menambah toilet dan membersihkannya secara berkala

e) Menambah tempat sampah

f) Membuat pagar pengaman untuk arena skateboarding 
g) Membuat pembatas untuk aktivitas banana boat

3) Strategi ST

Strategi yang menggunakan kekuatan untuk mengetahui ancaman

a) Perlu adanya penjagaan ketat untuk aktivitas berkemah agar tidak jadi aktivitas negatif selama perkemahan berlangsung

b) Membuat jalur khusus untuk bersepeda

4) Strategi WT

Strategi yang berusaha meminimalkan kelemahan untuk menghindari ancaman

a) Menambah spot untuk berfoto atau atribut berfoto

b) Membuat jalur khusus bersepeda

\section{KESIMPULAN}

Berdasarkan hasil penelitian dan pembahasan, kesimpulan Strategi Pengembangan Aktivitas Wisata di Objek Wisata Pantai Padang berikut ini:

1) Menambah area untuk berfoto atau atribut berfoto

2) Menambah fasilitas toilet

3) Membuat jalur khusus bersepeda

4) Memperhalus arena untuk aktivitas skakteboarding

5) Membuat pagar untuk arena skateboarding

6) Membuat pembatas untuk aktivitas banana boat

7) Menyediakan penyewaan sepeda

8) Menyediakan penyewaan alat kemah

9) Menambah tempat sempah

10) Menyediakan penjaga untuk aktivitas berkemah

\section{DAFTAR PUSTAKA}

[1] Sasmaya, Ayudia. 2018. Pengaruh Fasilitas Kamar Terhadap Kepuasan Tamu Menginap Di Grand Rocky Hotel Bukittinggi. Fasilitas Pariwisata dan Perhotelan Universitas Negeri Padang.

[2] Undang-Undang Negara Republik Indonesia No. 10 Tahun 2009 Tentang Kepariwisataan

[3] Undang-Undang Negara Republik Indonesia No. 9 Tahun 1990 Tentang Kepariwisataan

[4] Wahab, Salah. 2003. Manajemen Pariwisata. Jakarta: PT Pradya Paramitha.

[5] Karyono, A. Hari. 1997. Jakarta. Gasindo

[6] Mulyono, A., M. 2009. Aktivitas Belajar. Bandung: Yrama

[7] Angguni, Frisye. 2016. Strategic Planning Aktivitas Wisata di Panorama Bukik Siduali Tabek Patah. Padang: Universitas Negeri Padang (Skripsi yang tidak dipublikasikan)

[8] Ingkadijaya, Rahmad dkk. 2016. Aktivitas Wisata Pilihan Keluarga Perkotaan. Jakarta: Jurnal Khasanah Ilmu Volume 7 No. 1

[9] Juniva S, Silfeni S, Suyuthie H. (2017). Pengaruh Sarana Wisata Terhadap Kepuasan Di Objek Wisata Ngalau Indah Kota Payakumbuh. E-Jurnal Home Economic and TourismVol 15 Issue2

[10] Sugiyono. (2016). Metode Penelitian Kuantitatif, Kualitatif dan R\&D. Bandung: PT Alfabeta.

[11] Siswanto, Victorianus Aries. 2011. Strategi dan langkah-langkah penelitian. Pekalongan: Graha Ilmu 
[12] Habibah, Nur. 2015. Strategi Pengembangan Sarana dan Prasaran Objek wisata Danau Marambe Kabupaten Mandailing Natal. Skripsi Yang Tidak Dipublikasikan : UNP 